\title{
CHEMICAL ANALYSIS OF THE SEED OIL OF CANAVALIA ENSIFORMIS LINN. FOR
}

NUTRITIONAL AND INDUSTRIAL QUALITIES

Olubomehin, Oseyemi Omowunmi ${ }^{1}$, Atoyebi, Yisau Oluwatosin ${ }^{1}$, and Babarinde, Nojeem Adesola ${ }^{1}$ Department of Chemical Sciences, Olabisi Onabanjo University, Ago-Iwoye

Email of corresponding author: olubomehin.oseyemi@oouagoiwoye.edu.ng

\section{ABSTRACT}

The extensive demand for oils by man for consumption and industrial applications has led to an increasing search for oils from non-conventional sources to augment the available ones. Thus, the seed oil of Canavalia ensiformis Linn., a leguminous plant abundantly found in South-western Nigeria was extracted and analysed for its nutritional and industrial applications. Phytochemical screening and proximate analysis of the seeds along with physicochemical parameters of the oil using standard procedures were done. Different weights of the powdered seeds were extracted using a soxh let extractor with four solvents- n-hexane, chloroform, petroleum ether and ethanol. The fatty acid composition of the oil was characterized by Gas chromatography-Mass spectrometry (GC-MS),

Canavalia ensiformis seed contained saponins, anthracene derivatives, phenols, tannins, sapogenin $56.94 \pm 1.96,10.90 \pm 1.11$ for moisture content, protein, ash content crude fibre, carbohydrate, and oil extracts respectively. The physicochemical parameters of the oil were: $\mathrm{pH}-4.69$, specific araity$0.89 \pm 0.01$, acid value- 6.2 , saponification value- $203.3 \mathrm{mg} \mathrm{KOH} / \mathrm{g}$, free fatty acid-3.1, peroxide value18.50 and iodine value- $61.0 \mathrm{~g}$ of $\mathrm{I}_{2} / 100 \mathrm{~g}$ oil, while the oil is miscible with petroleum ether. The fatty acid compositions were 11-octadecenoic acid (43.86\%) 9-octadecenoic acid (27.49\%), hexadecanoic acid (17.07\%), cis-11-eicosenoic acid (4.32\%), ethyl cis-9-octadecenoate (3.80\%) and methy octadecanoate $(3.46 \%)$. The presence of $75.67 \%$ monoenoic acids in its composition, high saponification value, good foaming and emulsion properties makes the oil useful as an emollient, excipient in pharmaceuticals and solubilizing agents in aerosol products and also of great importance

Keywords: oilseeds, Canavalia ensiformis, saponification value, iodine value, peroxide value

Accepted Date: 15 April 2018

\section{INTRODUCTION}

ilseeds are leading suppliers of superior quality and specialty vegetable oils for nutritic products, natural food and premium snack food worldwide (Sarwar, 2013). Numerous researches have been done on the analysis of oilseeds because of the extensive demands for oils both for human consumption and industrial applications; consequently there is an increasing need to search for oils from non-conventional sources to augment the available ones and also to meet some specific applications (Kyari, 2008;Abitogun and Olumayede, 2008; Adepoju and Abiodun, 2013).

Oil seeds add important nutritional value to the diet due to the presence of high quality protein and also to vegetable oil, together with oil soluble vitamin like vitamin A (Abitogun and Oshodi, 2010).

Canavalia ensiformis Linn., belongs to the Leguminosae family. It is called Jack bean, horse bean, in English, 'Sesenla' in Yoruba and as 'Popondo' in Ijebu. It is the most common shrub in 'Popond in Ijebu it is the most common shrub in al, 1998). It is ich in al., 1998). It is rich in inclung those deficient in wheat (Lawal and Adebowale, 2005). It is usually planted in Nigeria as an ornamental plant grown near houses an allowed to trail on walls and trees and in some places as "snake repellant" (Udedibe, 1990). Young 
pods and beans of $\mathrm{C}$. ensiformis are eaten as vegetables but only after much preparation and cooking as they contain mild poison in the form of nti-nutritional factors such as protease inhibitors, ectins, saponins and tannins (Doyle et al., 2000; Kajita et al.,2001, Wojciechowski et al., 2004). Canavalia ensiformis has been investigated as a potential source of the urease enzyme which is also the source of concanavalin A, a lectin used in biotechnology applications, such as lectin affinity chromatography (Lewis et al., 2005). As with other legume seeds, a major drawback to the use of Canavalia ensiformis seeds in animal feeding is Cane presence of several entogenous toxic ant utritional factors (Carlini and Gumaraes, 1981), which include thermo-stable factors (canavanine, concanavalin, canavalin, canatoxin) and thermolabile factors (protease inhibitors, lectins, phytic acid). The aim of present study is to provide basic data on the chemical composition of $C$. ensiformis oil seed in Nigeria, evaluate the phytochemical potential and proximate analysis of the seed, physicochemical properties of $C$. ensiformis oil seed, and to assess the oilseed for both industrial and nutritional values.

\section{Materials and Method}

\section{Plant materials}

Fresh seeds of Canavalia ensiformis were harvested from Ago-Iwoye, Ogun State, Nigeria (N 065714.111 and E 03571 57.911). Identification and authentication were done at the Herbarium of the Forestry Research Institute of Nigeria (FRIN), Jericho Ibadan, where voucher specimen with FHI number 110444 was deposited.

\section{Seed preparation}

Canavalia ensiformis seed shell was manually opened to remove the seeds from the pods after which they were oven dried at $40^{\circ} \mathrm{C}$ until a constant weight is gotten. The seeds were pulverized using an electric blender, stored in labeled plastic bags until ready for analysis.

\section{Phytochemical screening}

The preliminary phytochemical analysis of the powdered sample were carried out to determine the presence of anthracene, saponin, tannins, phenols, flavonoids, alkaloids and cardiac glycosides using

\section{standard methods (AOAC, 1990).}

\section{Proximate Analysis of Oil seed}

This refers to the determination of the major constituents of the powdered sample and it is use to assess if a sample is within its normal compositional parameters or has somehow bee adulterated. This method grouped nutrients in samples into five components: moisture content, ash content, crude protein, crude fibre and ether extract. They were determined using the methods of AOAC (1990). The carbohydrate content of the seed was then determined by difference.

\section{Extraction Process}

A soxhlet extractor was used for extracting the oil using different solvents (petroleum ether, ethanol, chloroform and n-hexane). The solvents used were then recovered by simple distillation. Each solven $(300 \mathrm{~mL})$ was poured into a round bottom flask while $100 \mathrm{~g}$ of the powdered sample was placed in the thimble. The soxhlet was heated for $1 \mathrm{~h}$ to $50^{\circ} \mathrm{C}$ $60^{\circ} \mathrm{C}, 70^{\circ} \mathrm{C}$ and $80^{\circ} \mathrm{C}$ when using petroleum ether chloroform, $\mathrm{n}$-hexane and ethanol as solvent respectively. then removed from the round is and solve distled to remove the solvent, dried in the desiccator an weighed to determine the amount of oil extracted. The whole process was repeated and the weight of extracted oil was found to be the same in each case. Physicochemical parameters of the oil were then determined.

\section{Determination of the percentage of oil seed} extracted

Different weights of the powdered sample $(10,30$ 50,70 and $100 \mathrm{~g}$ ) were placed in the thimble and $150 \mathrm{~mL}$ of each solvent (petroleum ether, chloroform, n-hexane, and ethanol) was poured into the round bottom flask respectively. The soxhlet apparatus was heated for $1 \mathrm{~h}$ at $50^{\circ} \mathrm{C}, 60^{\circ} \mathrm{C}$ $70^{\circ} \mathrm{C}$ and $80^{\circ} \mathrm{C}$ for petroleum ether, chloroform, nhexane, and ethanol respectively. At the end, each solvent and extracted oil was distilled and the percentage of oil extracted was determined (AOAC, 1990).

Determination of Physicochemical Parameter The following physicochemical parameters were determined using standard procedures approved by
BPC (1988) and AOAC (1990): acid value, peroxide value, saponification value, solvent miscibility, $\mathrm{pH}$ value, density and specific gravity.

\section{Determination of Acid Value}

$5 \mathrm{~g}$ of extracted oil was weighed accurately into 200 $\mathrm{mL}$ flask and $25 \mathrm{~mL}$ of a mixture of equal volume of $96 \%$ ethanol and ether were added which had been neutralized with $0.5 \mathrm{~mL}$ dilute phenolphthalein solution. This solution was titrated with $0.1 \mathrm{M}$ $\mathrm{KOH}$, shaking constantly until a pink colour which persisted for about $15 \mathrm{~s}$ was obtained. The volume of $\mathrm{KOH}$ required was noted (BPC, 1988).

\section{Peroxide value}

To $1 \mathrm{~g}$ of the oil sample, $1 \mathrm{~g}$ of potassium iodide and $20 \mathrm{~mL}$ of solvent mixture (glacial acetic acid/chloroform, 2/1 v/v) were added and the mixture was boiled for one min. The hot solution was poured into a flask containing $20 \mathrm{~mL}$ of $5 \%$ potassium iodide. A few drops of starch solution were added to the mixture and the latter was titrated with $0.025 \mathrm{~N}$ sodium thiosulphate and the peroxide value was determined (AOAC, 1990) as follows:

$P V=S \times N \times 10^{3} / W$

Where $S$ is volume of $\mathrm{Na}_{2} \mathrm{~S}_{2} \mathrm{O}_{3}$ in $\mathrm{mL}, N$ is normality of $\mathrm{Na}_{2} \mathrm{~S}_{2} \mathrm{O}_{3}, W$ is weight of oil sample (g)

\section{Saponification value (SV)}

$2 \mathrm{~g}$ of the sample was weighed into a $200 \mathrm{~mL}$ flask. $25 \mathrm{~mL}$ of an ethanolic solution of $\mathrm{KOH}$ (prepared by dissolving $40 \mathrm{~g} \mathrm{KOH}$ in $20 \mathrm{~mL}$ of water and sufficient alcohol (98\%) was added to make 1000 $\mathrm{mL}$. The solution was allowed to stand overnight and the clear liquid was poured off. While the solution is still hot, $1 \mathrm{~mL}$ phenolphthalein indicator was added and titrated with excess of alkali using $0.5 \mathrm{~N}$ hydrochloric acid. The number of $\mathrm{mL}$ required (a) is noted. The operation was repeated without the sample being tested. The number of $\mathrm{mL}$ required (b) is noted (BPC, 1988).

$\mathrm{SV}=\{(\mathrm{a}-\mathrm{b}) \times 0.02805 \times 100\} /$ weight $(\mathrm{g})$ of sample

\section{Solvent miscibility}

This was determined by physical observation of the uniform blending of oil samples in petroleum ether and water at room temperature.
pH value, density and specific gravity

The $\mathrm{pH}$ value of the oil was obtained using a $\mathrm{pH}$ meter, a density bottle was used to measure the density at $25^{\circ} \mathrm{C}$ while the specific gravity determined by calculation.

Gas chromatography-mass spectrometry analysis (GC-MS)

GC-MS analyses were performed on a Thermo Fischer capillary gas chromatograph directly coupled to the mass spectrometer system (model GC ULTRA S/N 20062969; Polaris Q S/N 210729). HP-5MS non polar fused silica capillary column $(50 \mathrm{~m} \times 0.32 \mathrm{~mm}, 1.25 \mu \mathrm{m}$ film thickness) was used under the following conditions: oven temperature program from $40^{\circ} \mathrm{C}(2 \mathrm{~min})$ to $280^{\circ} \mathrm{C}$ at $5^{\circ} \mathrm{C} / \mathrm{min}$, and the final temperature kept for 10 min; injector temperature $250^{\circ} \mathrm{C}$; carrier gas $\mathrm{He}$, flow rate $1 \mathrm{~m} \mathrm{~L} / \mathrm{min}$; the volume of injected sample was $1.5 \mu \mathrm{L}$ of diluted oil in hexane; split less injection technique; ionization energy $70 \mathrm{eV}$, in the electronic ionization (EI) mode; ion source temperature $200^{\circ} \mathrm{C}$; scan mass range of $\mathrm{m} / \mathrm{z} 40-650$ and interface line temperature $300^{\circ} \mathrm{C}$. The constituents of the oils were identified based on their Kovat Index calculated in relation to the retention time of a series of alkanes (C4- C28) as reference products, in comparison with those of the chemical compounds gathered by Adams table (Adams, 2001), and the similarity of their mass spectra with those gathered in the NIST-MS library and or reported in the literature (Woerdenbag et al., 1993).

\section{RESULTS}

The results of the phytochemical screening of the powdered seed of Canavalia ensiformis is show in Table 1. The seed was found to contain tannin, saponins, emulsifying property, reducing sugar, phenol, steroids and alkaloids.

Proximate analysis of $\boldsymbol{C}$. ensiformis seed showed that it contained $1.50 \%$ moisture, $10.90 \%$ crude oil, $25.51 \%$ crude protein, $56.94 \%$ carbohydrate (by difference), $3.05 \%$ crude fibre and $2.10 \%$ ash as shown in Table 2 .

The extracted oil was bright yellow in colour and a liquid at room temperature. The oil content of the seeds for the four solvent sutilized is shown in 
Table3 with the oil extracted using petroleum ether giving the highest yield of $10.9 \%$ on average.

Physicochemical parameters are shown in Table 4 for Canavia ensiformis seed oil. The Tabecific ravity for Comavalia ensiformis oil seed was found to be 0.85 , the free fatty acid and the was value were deter. oleic acid respectively, saponification value (SV)

is $203.3 \mathrm{mgKOH} / \mathrm{g}$, and iodine value is 61.0

Table 1: Phytochemical screening of powdered seed of Canavalia ensiformis Secondary metabolites

Phenol

Flavonoids

Alkaloids

Tannins

Emulsifying Property

Saponins

Anthracene derivatives

-anthraquinone

-anthraquinone aglycon

-anthracene derivatives

Sapogenin and reducing sugar

$\mathrm{mg} / 100 \mathrm{~g}$ while the peroxide value was determined to be $23.50 \mathrm{~mL} / \mathrm{g}$.

The fatty acid composition of the oilseed showed that vaccenic acid, oleic acid, and palmitic acid are abundantly present; other fatty acid present were stearic acid, ethyl oleate, methyl stearate, an gondoic acid as shown in Table 5 .

\section{Key $+=$ Present in trace amount, $++=$ moderately present, $+++=$ abundantly presen} - absent

Table 2: Proximate analysis of Canavalia ensiformis seed powder Parameters

Moisture conten
Results

Moisture

$1.50 \pm 0.8$

Protein

$1.50 \pm 0.84$

Ash content

$25.51 \pm 0.21$

Crude fibre

$2.10 \pm 0.23$

Carbohydrate

$56.94 \pm 1.96$

Oil extracts

$10.90+1.11$

Table 3: Yield of Canavalia ensiformis Oil seed extracted using different solvents

\begin{tabular}{|c|c|c|c|c|c|c|c|c|}
\hline \multirow{2}{*}{$\begin{array}{l}\text { Sample } \\
\text { (g) }\end{array}$} & \multicolumn{2}{|c|}{ Hexane } & \multicolumn{2}{|c|}{ Chloroform } & \multicolumn{2}{|c|}{ Pet-ether } & \multicolumn{2}{|c|}{ Ethanol } \\
\hline & (g) & $(\%)$ & & & & $(\%)$ & $(\mathrm{g})$ & $(\%)$ \\
\hline 10 & 0.38 & 3.8 & 0.33 & 3.3 & 1.23 & 12.3 & 0.12 & 1.2 \\
\hline 30 & 1.10 & 3.6 & 1.00 & 3.3 & 3.27 & $10.9 \quad 0.35$ & 1.2 & \\
\hline 50 & 1.70 & 3.4 & 1.63 & 3.3 & 5.50 & 11.0 & 0.60 & 1.2 \\
\hline 70 & 2.50 & 3.5 & 2.25 & 3.2 & 7.63 & 10.9 & 0.85 & 1.2 \\
\hline 100 & 3.50 & 3.5 & 3.30 & 3.3 & 10.90 & 10.9 & 1.30 & 1.2 \\
\hline
\end{tabular}

Table 4: Physicochemical parameters of crude Canavalia ensiformis Crude Oil

$\begin{array}{ll}\text { Parameters } & \text { Results } \\ \mathrm{pH} & 4.69 \\ \text { Specific gravity }\left(27^{0} \mathrm{C}\right) & 0.89 \pm 0.0 \\ \text { Density }\left(\mathrm{g} / \mathrm{cm}^{3}\right) & 0.89 \pm 0.01 \\ \text { Solubility }(\mathrm{ether}) & \text { miscible } \\ \text { Acid value } & 6.2 \\ \text { Saponification value }(\mathrm{mgKOH} / \mathrm{g}) & 203.3 \\ \text { Free fatty acid(\% oleic acid) } & 3.1 \\ \text { Peroxide value } & 18.50 \\ \text { Iodine value }\left(\mathrm{g}_{\text {of }} \mathrm{I}_{2} / 100 \mathrm{~g} \text { oil }\right) & 61.0\end{array}$

Table 5: Fatty acid compositions of Crude Canavalia ensiformis Oil Old name

11-Octadecenoic acid

9-Octadecenoic acid

Hexadecanoic acid

Vaccenic aci

Oleic acid

Palmitic acid

Cis-11-Eicosenoic acid

Ethyl cis-9-octadecenoate

Gondoic acid

Ethyl Oleate

Methyl octadecanoate

Methyl stearate

Results
43.864
27.492
17.072

27.492

17.072

4.318

3.798

3.456

\section{Discussion and Conclusion}

The phytochemicals present in the seed sample of C. ensiformis is an indication that the plant is of pharmacological importance. The observed phytochemicals are of great biological and biochemical importance in the human system. Tannins when taken in excess are found to be harmful to man (Ferreira et al., 2008) due to its ability to chelate with metal ions rendering them unavailable to the human system. The oil extracted with petroleum ether had the highest yiel with petroleum ef $10.9 \%$ on average, this is due to the increased ability of the solvent to overcome forces that bind lipids within the sample matrix (Lumley et al., 1991) and also the polarity of the solvent and the oil. The low percentage of oil makes this seed not to be a potential raw material for the oil industry. According to Egbekun and Ehieze, (1997), variation in oil yield may be due to the differences in variety of plant, cultivation climate, ripening stage, the harvesting time of the seeds, the extraction method and solvent used. The low $\mathrm{pH}$ of 4.69 suggests the presence of a reasonable amount of fatty acids in the oil, which is a good indicator of the advantageous utilization of the oil. The preferential solubility in petroleum ether shows that the oil has a high level of unsaturated fatty acids (bearing in mind that oils rich in unsaturated fractions are readily soluble in ether),implying that the oil can undergo polymerization and this imparts on the oil a level of industrial utility (SLTC, 1963). The acid value in the oil of C. ensiformis being $6.20 \%$ Oleic is comparable to $6.4 \%$ given by Abitogun and Olaseheinde, (2012). The free fatty acid value was determined to be $3.10 \%$ oleic acid thus; there are corresponding high levels of free fatty acids in the oil, which suggest high level of hydrolytic and lipolytic activities in the oil. The value is an indication that the oil can be refined to edible vegetable oil. The saponification value (SV) of $203.3 \mathrm{mgKOH} /$ gis comparable to those reported by Kyari, (2008) and also for common oil such as palm oil, groundnut oil and coconut oil (SV is 200,193 and $257 \mathrm{mg} \mathrm{KOH} / \mathrm{g}$ respectively)thus, this oil may be used in soap making. The iodine value of 61.0 
$\mathrm{mg} / 100 \mathrm{~g}$ was comparable to that obtained for $C$. ensiformis $67.2 \mathrm{mg} / 100 \mathrm{~g}$ by Abitogun and Olaseheinde, (2012). ensiformis when compared with the iodine values of Bligiasapida $89.6 \mathrm{mg} / 100 \mathrm{~g}$, castor oil 87.72 $\mathrm{mg} / 100 \mathrm{~g}$ and olive oil $81.0 \mathrm{mg} / 100$ gall of which are non-drying oils (Akpan et al., 2006; Kyari, 2008) suggests that this oil could be better as anondrying oil and this could be significant during cargo handling and tank cleaning. The peroxide value was determined to be $18.50 \mathrm{~mL} / \mathrm{g}$; which is low and indicative of a low level of oxidative rancidity and of antioxidants. The combination of low iodine value and low peroxide value suggests that the oil could also be stored for a long period without deterioration. These also show that the oil possesses the desirable qualities of edible oils and could therefore be used for food purposes and as a feedstock in the industries. The specific gravity for C. ensiformis oil seed was found to be 0.85 which was similar to 0.87 reported for crude Laffa cylindrical oil by Abitogun and Olumayede, (2008) but lower to crude soya bean oil, sunflower oil reported by Abitogun and Oshodi, (2010).

Oleic acid (in triglyceride form) is included in the normal human diet as a part of animal fats and vegetable oils. Oleic acid as its sodium salt is a major component of soap as an emulsifying agent, and can also be used as an emollient (Carrasco, 2009). Small amounts of oleic acid are used as excipients in pharmaceuticals, and as an emulsifying or solubilizing agent in aerosol (E)-Octadec-11-nic acid, also (E)-Octadec-11-encic acid is a naturally ccurring trans-fatty acid found in the fat of ruminants and in dairy products such as milk, butter, and yogurt. It is also the predominant fatty acid comprising trans-fat in human milk (Precht and Molkentin, 1999).

In conclusion, the phytochemicals present in the sample is an indication that the plant is useful pharmacologically. The presence of more than $70 \%$ ponoenoic acid in its composition, high maponification value, its cood foaming and mo ents only as a solubilizing agent in aerosol products, an emollient and excipients in pharmaceuticals, but also of great importance in soap and cosmetics industries. It could be used in food systems as a functional ingredient after modification to improve functionat properties. Overall, Canavalia ensiformis has good nutritional quality and can be used as functional foods.

\section{Acknowledgment}

The authors wish to acknowledge the technical assistance rendered by Mr. J.A. Adegoke.

\section{References}

Abitogun, A. S., and Olasehinde, E. F. (2012) Nutritional evaluation of seed and characterization of crude Jackbean (Canavalia ensiformis) oil. Journal of Applied Chemistry, (IOSRJAC) 1(6): 36 40

Abitogun, A. S.,and Olumayede, E.G. (2008) Extraction and characterization of Luff cylindrical oil. Journal of Applied Sciences, 28: 112-119.

Abitogun, A.S., and Oshodi A. A. (2010). Effects of degumming and bleaching on the Physicochemical parameters of crude Sunflower oil. Jou Sunflower oil. Journal of Chemical Society
of Nigeria, 35(2):57-61.

Adams, J. A. 2001. Kinetic and catalytic mechanisms of protein kinases. Chemistry review, 101 (8): 2271-2290

Adepoju, T. F., and Abiodun, A. (2013). Statistica approach to oils extraction from sorrel seed (Hibiscus sabdariffa L.) and its quality characterization. International Journal of Science and Engineering Research, 9(4): 122-123.

Akpan, U. G., Jimoh, A. and Mohammed, A. D. (2006). Extraction, characterization and modification of Castor seed oil. Leonardo Journal of Sciences 8: 43-52

AOAC. (Association of Official Analytical Chemists). (1990). Official Methods of Analysis (15th edn). AOAC: Washington DC

BPC. (1988). British Pharmacopoesis .Office of the British Pharmacopoesis Commission. London.

Carlini, C. R and Gumaraes, I. (1981). Isolation and characterization of toxic protein from Canavalia ensiformis (jackbean) seeds distinct from Concanavalin A. Toxicon 19:
667-675.

Carrasco M. (2009). Attention: Psychophysical approaches. In T. bayne, a. Cleeremans \& P. Wilken (Eds), the Oxford companion to consciousness. Oxford, UK: Oxford University Press, pg. 93

Doyle, J. J., Chappill, J. A., Bailey, C. D., and Kajita, T. (2000). Towards a comprehensive phylogeny of Legumes: Evidence from rbcL sequences and non-molecular data. 120 in Advances in Legume systematics, Part 9, (P.S. Herendeen and A. Bruneau, eds.). Royal Botanical Gardens, Kew, UK

Egbekun, M. K. and Ehieze, M. U. (1997). Proximate composition and functional properties of full fat and defatted beni seed (Sesamum indicum L.) flour. Plant Foods Human Nutrition, 51:35-41.

Ferreira, D., Gross, G. G., Hagerman, A. E., Kolodzied, H. and Yoshida, T. (2008). Tannins and related polyphenols: perspective G. Their chemistry, biology, ecological effects and human health protection. Photochemistry, 69: 30063008 .

Kajita, T., Ohashi, H., Tateishi, Y., Bailey, C. D., and Doyle, J. J. (2001). Legume phylogeny, with particular reference to Phaseoleae, Millettieae, and allies. Systematic Botany 26: 515-536.

Kyari M. Z. (2008).Extraction and characterization of seed oils. International Journal of Agrophysics, 22:139-142

Lawal, O. S and Adebowale, K. S. (2005). The acetylated protein derivatives of Canavalia ensiformis (Jackbean): A study of functional characteristics. LWT - Food Science and technology, 39 (8): 918-929.

Lewis, G., Schrire, B., Mackinder, B. and Lock, M. (2005). (eds.) Legumes of the world. The Royal Botanic Gardens, Kew, Reino Unido. 577.

Lumley, I. D. (1991). Fats from Fatty Foods and Determination of Fat Content. In Analysis of Fats and Fatty Foods. Rossell, J. B and J. L. R. Pritchard, (Eds.): 238-247.

Precht, D and Molkentin, J. (1999). C18:1, C18:2, and $\mathrm{C} 8: 3$ trans and cis fatty acid isomers including conjugated cis delta 9 , trans delta 11 linoleic acid (CLA) as well as total fat composition of German human milk lipids, Nahrung, 43(4) :233-244

Sanchez-Vioque, R. Clement, A., Vioque, J. and Millian, F. (1998). Polar Lipids of defatted Chickpea (Cicerarietium L) flour and protein isolates. Food Chemistry, 63: 357 855.

Sarwar, M. (2013). The theatrical usefulness of olive Olea europaea L. (Oleaceae Family) nutrition in human health: A Review. Sk Journal of Medicinal Plant Research 2 (1): $1-4$.

SLTC. (1963).The Society of Leather Trader Chemists Official methods of Analysis.

Smolinske, C. (1992). Handbook of Food, Drug, and Cosmetic Excipients. pp. 247-248.

Udedibie, A. B. I. (1990). Nutritional evaluation of jackbean (Canavalia ensiformis) for the Nigerian poultry industry. $A M B I O, 19: 361$ 365

Woerdenbag, H.J., J.F.J. Lüers, W. van Uden, N Pras, T.M. Malingré, and A.W. Alfermann. 1993. Production of the new antimalarial drug artemisinin in shoot cultures of Artemisia annua L. Plant Cell Tissue Organ Culture 32:247-257.

Wojciechowski, M. F., Lavin, M., Sanderson, M. J., and Lavin, S. (2004)."A phylogeny of legumes (Leguminosae) based on analysis of the plastid mat $\mathrm{K}$ gene resolves many well-supported subclades within the family". American Journal of Botany, 91 (11): $1846-1862$ 